\title{
A Sustainable Rural Telecentre Concept on Sustainability Pillars
}

\author{
Marhaini Mohd Noor ${ }^{1}$ \\ ${ }^{1}$ Faculty of Maritime Studies, Universiti Malaysia Terengganu, Kuala Nerus, Malaysia \\ Correspondence: Marhaini Mohd Noor, Faculty of Maritime Studies, Universiti Malaysia Terengganu, 21030, \\ Kuala Nerus, Terengganu, Malaysia. Tel: 09-668-3485. E-mail: marhaini.noor@umt.edu.my
}

Received: June 2, 2021

doi:10.5539/jsd.v14n6p42
Accepted: October 7, $2021 \quad$ Online Published: November 3, 2021

URL: https://doi.org/10.5539/jsd.v14n6p42

\begin{abstract}
Over the years, Information and Communication Technology (ICT) has become more relevant in today's society. A telecentre is a community centre where people use, access and utilizes the benefits of the centre through the ICTbased services provided. This paper reviews rural telecentres in Malaysia. The roles and functions of telecentres are explained and discussed to analyze the question on sustainability. The 'Just Transition' is a recent and particular transition for rural telecentre to be sustained. Based on the qualitative analysis and review of telecentres' sustainability, we found that some telecentres can be sustained while others could not. This is because of the impacts of economic, social, environmental and policy sustainability pillars on community telecentres in Malaysia. The review of this paper reveals findings obtained from in-depth interviews with telecentre managers and telecentres' sustainability depends on natural resources, geographical location, social entrepreneurship, social capital, human resources (competency of leaders) and basic infrastructure. Therefore, future research should be focus on the roles of governance on resource utilization and implement effective public policy for telecentres' sustainability.
\end{abstract}

Keywords: ICT, rural telecentre, telecentre sustainability, sustainability pillars, Malaysia

\section{Introduction}

This paper reviews the sustainability of telecentres in Malaysia. The focus is on rural telecentres. Rural telecentres provide applications of Information and Communication Technology (ICT) to empower community processes and achieve community objectives including to support the community and sustain the telecentre (Gurstein, 2000; Furuholt and Saebo, 2018). Telecentre programs have been one such policy response by developing countries in seeking to reduce poverty and improve quality of life. However, telecentre programs in rural communities have been problematic and difficult to maintain and sustain in the long term. This is due to sources of external funding and appropriate resources; such as financial and people (Proenza et al., 2001; Furuholt and Saebo, 2018). Therefore, this study analyses the sustainability of telecentres based on four pillars of sustainability (economic, social, environment and policy); whereby the pillars examined how the telecentres are sustained and remain relevant to the needs of local communities. Nevertheless, there are challenges towards sustainability that need to be overcome for telecentres' effectiveness. The main challenge is the sustainability of the telecentre programs. Several factors, such as lack of inputs (technology, people and physical environment), lack of availability of relevant digital content, low income, and high operating cost have been identified as challenges of sustaining telecentre programs. Hence this study reviews and analyzes telecentres' sustainability that best address the needs of local communities.

\section{The Telecentre Concept}

Telecenter is also known as a rural information technology center where it is a hub-technological rural area for locals utilizing technology (Lee, 2010). Typically, telecenter provides some ICT equipment such as computers, internet, printers, and digital cameras. In addition, telecenter is also a non-profit public place where the public can access free computers and other digital technologies equipped with software and connected to the internet (Short, 2001).

In addition, telecentres are accessible centres that enable technology and connectivity to be within the practical physical reach of community members by conveniently locating them within the community, as well as providing affordable computer and internet access at low or no cost (Prado and Janbek, 2013).

In addition, there are also telecenters that provides computer classes and computer workshops to the community with the aim of introducing appropriate technology to meet individual and community needs (UN, 2006; Nemer, 
2015). Most telecenters have the same goal of introducing technology to the community as well as facilitating the community to apply technology in their lives (Telecentre.Org, 2011).

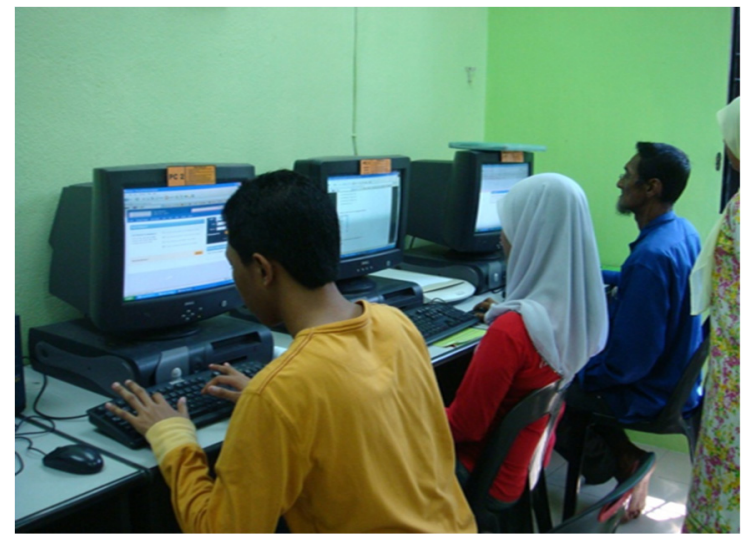

Source: Adapted from Marhaini, 2013

The digital divide problem can occur anywhere in the world whether in developing countries or for industrialized countries, for example in the United States the digital gap between the black and white communities (Zaiton and Barbara, 2005; UN-APCICT, 2010). Shows or indicates that the digital divide is a frequent issue and will always be addressed by any organization or community to find solutions to bridge the gap that exists. Malaysia is also not an exception in addressing this digital divide issue which Zaiton and Barbara (2005) states that the digital divide in Malaysia is growing and should be noted by certain parties to find solutions. A significant digital divide in Malaysia still exists and this will cause economic divide; due to quality of access is low to the underserved and inconsistent or poor quality of Internet connectivity. Therefore, there is the need for high-speed or large band width internet more affordable for Malaysians (World Bank, 2019). Due to the digital divide and technology obsolescence, all telecentres are struggling to maintain and secure their technology and equipment. Some telecentres in South Africa, for example, are experiencing a lack of functioning computers and slow Internet connections (Attwood and Braathen, 2010).

A quite similar case is the system of community facilities in parts of Africa, where the public library is commonly used (UNDP, 2001; ITU, 2011b). The use of telecentres in Africa has been reduced because of inappropriate locations and are not comfortable for users. The location affected accessibility and the use of facilities in some telecentres. Usually the available space was too small or there was the problem of inadequate physical facilities such as toilets (Etta and Parvyn-Wamahiu, 2003). Similarly, Harris (2007) pointed out that telecentres in Malaysia lacked toilets for users, had unreliable power, were prone to flooding and had insufficient space. Recently, Telecentre Programme for Orang Asli (TPOA) in Sarawak, West Malaysia is a community-university based initiative in partnership with the Department of Orang Asli Development (JAKOA) is committed to develop community telecentre as a platform to enhance quality of life. TPOA also facing problems with internet connectivity and accessibility (UNIMAS, 2019; Chong et al; 2020).

In addition, there are many supporters of telecenter movement classifying services provided by telecenter as community development and referring telecenter to telecenter community (Parkinson, 2003). This is so, the community is closer to the telecenter as telecenter is more focused on rural communities and is particularly useful for low-income communities. The right to information is a basic necessity for today's community in which Bangladesh makes a community information center such as telecenter to develop digital Bangladesh (Anwarul and Keita, 2011). In addition, local communities will be able to access the digital world with a community information center.

\section{Roles and Functions of Telecentres}

The execution of the telecenter was created to help connect people who could not apply ICT so that they could equip themselves with this facility (Jalaluddin, Norizan and Jamaluddin, 2010). In addition, telecenter will be able to help empower marginalized communities such as rural people, indigenous people, the elderly, the poor, and the disabled. Hence, ICTs that are often only enjoyed by residents in urban areas and easily accessible by the capable people will trigger a digital divide among marginalized communities that cannot apply ICT in their daily lives. However, the telecenter existence is a turning point and helps the socioeconomic situation of the people and would be able to improve the country's economy and society (Pigg, 2003). 
The digital divide will lead to inequality in the level of ability to get education, employment, gain important health information and so on (Skaletsky, 2013). The country's economic and social development will also be stunted and confined to a marginalized community of internet access to keep up with communities with internet access. Hence, as stated by Smoot (2007), the digital divide will worsen household economic inequality in rural and urban areas. Meanwhile, the existence of telecenter as a medium to bridge the digital divide is seen as the right catalyst to bridge the gap (Davies et al; 2003-refer Appendix).

Telecentres are also seen as an answer to some of the problems of the digital divide (whereby large sections of society do not enjoy access to ICTs and are seen to be excluded from the socio-economic benefits). Hence, the delivery of socio-economic benefits via telecentres is a strategy of community development and poverty reduction (Harris, 2007). In developing countries such as Africa, Latin America and Asia, telecentres are viewed as a new solution to development problems in terms of ICT accessibility and bridging the digital divide (Gnaniah et al., 2006). As a result, telecentres in Bangladesh have been established many years ago. The telecentre proved that it is a tool to bridge digital divide and improve rural community quality of life. The challenge of digital divide needs to be overcome by introducing public-private partnerships (PPPs) concept in Bangladesh telecentre. The partnership is a cooperation and collaboration to share risks, resources, goals and decision-making. This concept has been accepted in Bangladesh and expected to increase in the future. PPPs in ICT services would be more effective and quality services provided in lesser time, lower cost and less corruption hence increase community satisfaction on public service delivery and administration (Hoque et.al, 2019).

Many studies have shown that the digital divide has led to an increasing wealth gap between rural and urban areas in developing countries (Fong, 2009; Black and Atkinson, 2007; Furuholt and Kristiansen, 2007) and even a developed country such as the UK is experiencing a similar divide (Essays UK, 2013). In rural Malaysian communities, the level of income tends to be low, and the cost of computers and other ICT facilities are beyond the means of a large proportion of the rural population. The low level of computer usage in these communities is associated with low computer or ICT literacy and the inability to realize the benefits of ICT in improving their quality of life (Mahendhiran, 2010).

According to Tizala (2011), telecenter is a strategy to improve the quality of life of the poor who need to be concerned about whether they benefit or access appropriate or just the provisions provided. Therefore, a detailed study of the benefits of a subordinate or marginalized community should be emphasized to ensure that the outcomes / results are positive. However, technology solutions such as this telecenter can be wasted if the community is not interested in joining or utilizing it (Simms, 2004). Referring to the telecenter program in Malaysia, the government has allocated RM150 Million for the development of this program which is a huge investment (MCMC, 2013).

\section{Sustainability Concept of Telecentres}

Sustainability of a Telecentre is the "Capacity to generate enough revenue from ICT enabled services to ensure continues existence in the community, fulfilling the socio-economic well-being of the society" (Niranjan M, 2009; Chong et al; 2020). The problem related to this research is policy failure at the institutional capacity. This takes the forms of insufficient inputs or resources for this program, namely the lack of funding, inaccurate information, time constraint, obsolete computers and other insufficient basic infrastructure. However, this review is aimed at the implementation of the program, which is still at a very basic level and need for more broadband facilities in terms of delivering the training, and also for speedy use of internet services. Despite the activities of the program, the program contents require more emphasis in terms of the training contents; whereby they need to be shared and must not be isolated. The information for business should be widely spread between local entrepreneurs and other entrepreneurs in across the regions (Jensen and Esterhuysen,2001; Marhaini MN, 2014).

A study in Bangladesh evidenced to consider long-term sustainability of telecentres, which focused on telecentre functions and training opportunities for entrepreneurs. Therefore, the ICT services provided must meet the needs of rural community and socio-economic challenges in Bangladesh. Thus, an improvement in telecentre environment and ICT skills related to entrepreneurs are essential in rural Bangladesh (Hoque et.al, 2019).

According to the Brundtland Commission Report, sustainability is a process of constant development in economy, society and environmental aspects for better future plan and accommodates changes at present. These aspects are known as pillars of sustainability (Van Dyk, 2018). The pillars are economic sustainability, social sustainability, environmental sustainability and policy sustainability. Indeed, financial sustainability is a must if a telecentre is to be sustained. Much also depends on the long-term commitment of key staff, the long-term stability of finance, and the ability to remain relevant to community needs. These are the biggest challenges facing organizations wanting to support the development of community information and technology centers. More importantly, how can they 
ensure that the centers they are proposing will receive adequate funding in the long term?

\section{Methodology}

This study employs research method on qualitative analysis. The research was conducted from September 2018 until December 2020. The analysis was obtained from in-depth interviews with telecentre managers. A purposive sampling of three telecentres in rural areas of Terengganu state, Malaysia. The telecentres were FELDA Belara, Kuala Berang and Kampung Padang Jambu. These telecentres were selected due to majority of the household income falls under B40 group (UPEN, 2016) and the centre is a must for them to improve their quality of life. The interviews were conducted in January 2020 with the respective telecentre managers. The main objective of this study is to review the rural telecentre program transition and sustainability. The idea is to examine whether the telecentre could be sustainable or not based on the four pillars of sustainability. Besides interview, a general observation also applied to this study.

The observation was conducted while visited the three telecentres. It took several days to observed the centres and gather the inputs or information for telecentre sustainability. During the observation, rural communities were busy with their accessibility on ICT services provided at the telecentre. Most of the users were youngsters and female, thus they understand the importance of telecentre to their well-being. When the users visited the telecentre, they built networking (social and business), increase ICT knowledge and skills and also be able to participate in activities and workshops facilitated by the telecentre managers. Hence the idea of sustainability is significant to these users (rural community).

The reviews were also made based on previous study from literature. Based on this secondary data; users need the telecentre to improve their quality of life, however the telecentres are facing challenges to cope with sustainability. Most of the studies focused on the impact of telecentres to users and the studies were mostly in developing countries. Thus, this study changes the perspective on impacts to sustainability. People found that the telecentre benefits socio-economic impact and this leads to rural and sustainable development.

A thematic analysis was constructed to generate key findings and concepts for the analysis. Based on the themes, the sustainability was identified from four pillars of sustainability; which were: (1) economic sustainability, (2) social sustainability, (3) environmental sustainability and (4) policy sustainability. Thus, the key findings were explained and discussed as follows.

\section{Findings \& Discussion}

The main findings indicated in this study are the four pillars of telecentre sustainability. Which are; economic sustainability, social sustainability, environmental sustainability and policy sustainability. These pillars are crucial for telecentre sustainability. Therefore, each pillar is explained separately.

\subsection{Economic Sustainability}

Economic sustainability includes employment opportunities, ending poverty, sustaining economic growth and expanding infrastructure (Van Dyk, 2018). In this context, telecentres' sustainability depends a lot on social entrepreneurship. The outcome of a successful program should result in job opportunities, better infrastructure, sustained income generation and better education for local communities. These are the elements of economic sustainability at telecentres. Thus, social entrepreneurship at telecentres should be aimed at financial sustainability as there is no funding from government to assist telecentres. In order to be sustained, telecentres must be selfsufficient financially. With the existence of social entrepreneurship club (SEC) at telecentres, the impact relies much on sustainability which is relevant to eradicate poverty and sustained economic growth in rural areas. This is the economic impact of telecentres (Lwoga and Chigona, 2019, Kapondera and Namusanya, 2017).

Table 1 is a summary of the functions of a successful social entrepreneur club (SEC) of a telecentre and identifies the impact or outcome on each of those functions. The purpose of the club is to recruit local community members to become entrepreneurs and create jobs, wealth and also improve their quality of life. The SEC is seen as a critical initiative which could generate income for the telecentre program and thus sustain the telecentre financially (selfsustainability). Furthermore, the club can be successful if the telecentre can convince local community members of the benefits gained by individuals to become entrepreneurs and having their own businesses (Marhaini MN, 2013). 
Table 1. Social entrepreneurs club (SEC)

\begin{tabular}{ll}
\hline Functions: & Economic \& Social Impact/Outcome: \\
\hline 1) Business operations & Economic and Self-Sustainability \\
2) Job opportunity & Economic Sustainability \\
3) Business and social networking & Social Sustainability \\
4) Strong committee and participation & Social Sustainability \\
5) Improve quality of life & Social \& Economic Sustainability \\
\hline
\end{tabular}

Source: Marhaini, 2013

In addition, local community members can develop their businesses through the social relationships built through the SEC. This is because entrepreneurs are able to do a lot of networking through the SEC, as well as facilitating the socialization of entrepreneurs within rural communities. For example, entrepreneurs first develop social relationships or networking, then they will engage in building business networks. The entrepreneurs have also realized that economic benefits achieved also contribute to the telecentres' benefit (Kapondera and Namusanya, 2017, Marhaini MN, 2013).

Membership of SECs bears benefits in terms of social relationships within members and other local communities. Moreover, members also perceived that social capital can be built around the social contacts, social and business relationships that exist at telecentres and SECs. At SECs, the participants not only gained the benefits of business opportunities but the social benefits as well. The findings suggest that, overall, telecentre users believe that they have gained economic benefits as well as strong bonding, bridging capital and local community association. Therefore, this would lead to an improvement in quality of rural life for the individual communities (Marhaini MN, 2013).

\subsection{Social Sustainability}

Social sustainability is equality, equity, access to basic services, health, safety, education, food security and quality of life (Van Dyk, 2018). Social sustainability in a telecentre context refers to social capital which focus on bonding and bridging capital. This is due to the local community principle on trust, close relationships, acquaintance and beliefs. This concept assumes that people will work together if they have high social capital. This is in an agreement with study done in Tanzania on telecentre usage where majority users used telecentres for strong social capital (social purposes) such as communicating with distant relatives or family (Lwoga and Chigona, 2019). Therefore, programs provided by the telecentres as well as the social entrepreneurship activities lead to improvements not only in the quality of life but also in social sustainability. This will eventually result in social change for the community brought about by the existence of telecentres.

The quality of interactions between telecentre managers and the management committees also has a bearing on the effectiveness of the telecentres (Murray et al; 2001). It has been revealed that low or inferior interaction levels between telecentre managers and management committees (as well as the absence of management committees) adversely affect the level of commitment between telecentre managers and management committees. This is in contrast to other key stakeholders who have good working relationships (Raul and Colle, 2002). This shows the importance of the managers' role and initiative; of how they work with the committees and impediments to the users' participation in the program. For instance, if there is less commitment from the committee and the working relationship is not working well, this could lead to less users' involvement at telecentres, as the committee members are influential persons at attracting users. Without this, the telecentres could not be sustained (Marhaini MN, 2013). Therefore, some possible responses to this relationship are: (1) committee training and (2) more engagement between telecentre managers and management committees (Raul, 2000). This might be due to different telecentre managers have different capabilities on how to operate their respective telecentres successfully.

\subsection{Environmental Sustainability}

Environmental sustainability refers to the control and appropriate level of exploitation and use of scarce natural resources (Van Dyk, 2018). The telecentre aspect of environmental sustainability is not just natural resources but also includes human resources, the location or geography of telecentres and basic infrastructure provided. The geographical location of telecentres determines the natural resources available by indicating agriculture areas, entrepreneurship hub and tourism attraction mainly. This has affect the commitment of telecentre managers and the level of basic infrastructure made available. Some telecentres may be sustainable because of the location with 
natural resources available for consumption and production. Hence the active participation of telecentre managers will result in positive environmental impacts. A study in Tanzania, rural women facing problems with poor ICT infrastructure and lack of natural resources available in some geographical location of telecentres. The ICT infrastructure is limited, with insufficient electrical supply and inadequate access to the internet are the barriers of environmental sustainability (Lwoga and Chigona, 2019). According to Muhammad Sani et al (2011), the competency of leaders (human resources) and infrastructures are the main factors contributing to the success of telecentres and their sustainability.

It is imperative to note that some telecentres in Malaysia lack adequate computers, and some have outdated hardware and equipment. Telecentre managers have also identified that there is a need to add more computers and upgrade the hardware, software and other ICT tools. The telecentre spaces tend to be small and uncomfortable for users. However, there are still users who continue to participate in the program. This shows that despite the absence of adequate physical space, the success of the program can be attained if users feel that they can benefit from it. Observations of bigger telecentres reveal that they have similar number of users, usage, and facilities available (Gomez, 2012). Thus, discrediting the relationship between space availability and the number of users, usage and facilities. There is little funding available for the physical resources however, some telecentres do receive funding from local authorities for toilets inside the buildings (Marhaini MN, 2013).

Also, there have been perceptions that the nonstrategic locations of telecentres would discourage the telecentre users from becoming entrepreneurs or attracting existing entrepreneurs to join the SECs. For example, there are entrepreneurs in some areas of rural Malaysia despite the absence of the SECs. This appears to be a problem for those telecentres that are located in rural areas with agriculture as their main economic activity (Marhaini MN, 2013).

It is important to note that the layout of a telecentre also affects its ability to attract users. Therefore, the space or premise of a telecentre should be organized in a specific manner. The layout of a telecentre premise is as shown in Figure 1.

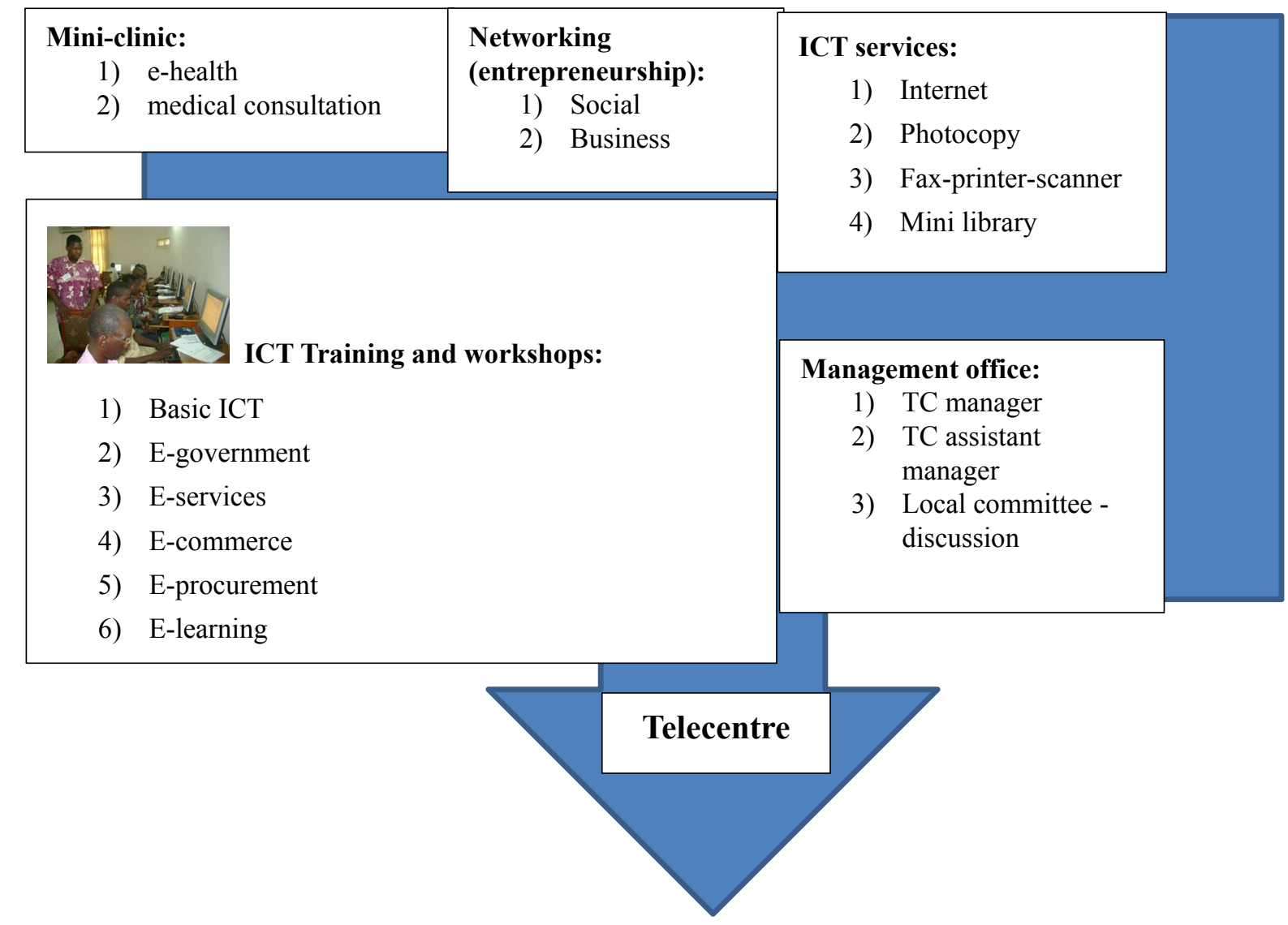

Figure 1. A layout on an organized telecentre premise

Source: Adapted from Harris, 2007 


\subsection{Policy Sustainability}

Policy aspects of telecentre sustainability include poverty reduction policy, rural development policy and information and communications technology (ICT) policy. The poverty reduction policy is to achieve millennium development goals (MDGs). This is to provide access to ICTs for the poor; for them to access usage, utilize benefits and opportunities of ICT (Harris, 2007, Kapondera and Namusanya, 2017). Thus, important criteria for poor people to make use of ICT is to make it accessible and affordable to them. Hence, with the poverty reduction policy, this will narrow digital divide among the poor and rural community. As a result, this will lead to rural and community development.

In Asia, poverty is mostly located in rural areas and which have low access to ICTs. The use of ICTs is a low priority and it is up to the Ministry of Rural Development to play a proactive role to address this concern (Harris, 2005 ; 2007). That is why the rural development policy is important and it takes part of policy sustainability.

In addition, the formulation of telecentre programs and access to telecommunication and internet services with the integration of poverty reduction and rural development policy, is also important. This is known as ICT policy and includes telecommunication and also internet policies (Harris, et al; 2003, Harris, 2007). This policy can promote telecentres' importance as factor of development. An explanation on the importance of telecentre for development is illustrated in Table 2.

Table 2. Telecentre sustainability for development

\begin{tabular}{lll}
\hline \multicolumn{1}{c}{ Policies } & \multicolumn{1}{c}{ Development Outcomes } & \multicolumn{1}{c}{ Development } \\
\hline Poverty Reduction & -Provision of education and training to the & Community Development \\
Policy & rural communities & Human \\
& -Increased community empowerment & Development \\
& -New job opportunities & Economics Development \\
\hline Rural Policy & - Improved efficiency of government service & Rural Development \\
& delivery; rural areas & Agriculture Development \\
& -Increased access to commodity and market & \\
prices; farmers, fishermen & \\
\hline ICT Policy & -Improved information and communication & ICT Development \\
& -Improved access to basic government & Technology Development \\
& information and services; i.e.: e-government, & \\
& e-health & \\
\hline
\end{tabular}

Source: Adapted from Breitenbach, 2013

Referring to Table 2 on telecentre sustainability for development, the three policies are the elements for policy sustainability. These policies are the source for development. Therefore, as adapted from Breitenbach 2013, the development outcomes are recognized as components for telecentre sustainability. Thus, brings the notion that the success of telecentres depends on policies implemented and as a result of development.

\subsubsection{Green Agenda Policy}

As part of policy sustainability, green agenda policy is also useful for sustainability agenda in Malaysia. The Green policy is a commitment to sustainability and technology adoption and adaptation of the environment. In this context, the rural telecentre as the environment to be adapted by the technology or ICT for sustainability (Essays UK, 2013). This agenda is as part of green economy and industrial revolution 4.0 to achieve sustainable development goals (SDG) 2030. Thus 'green' means in this case, the knowledge and practices of rural telecentres to be sustainable must be environmentally friendly and ecologically responsible decisions making made by stakeholders (A. Aziz, et.al, 2018).

Rural telecentre will be sustainable if the technology is affordable, the people having strong relationships, safe and secure environment with good location. Therefore, interconnectedness with the other rural telecentres in the world and taking corrective action towards telecentre environmental responsibility are also green agenda and part of the 
policy. The need for greening ICT infrastructure is making ICT to reduce the electricity consumption and improve the environment on climate change.

\subsection{Telecentre Sustainability in Malaysia}

A telecentre is said to be sustainable if the effectiveness program implemented is relevant to meeting the needs of the community. Therefore, this paper discusses the telecentre sustainability challenges and the improvement of telecentre programs. Based on this study's review, factors of challenge are financial stability, human resources, technology and infrastructural environment.

Most telecentres have been found lacking in terms of the funding for operational expenses associated with telecentre, and most importantly capital investment in new ICT infrastructure to underpin the telecentre program. As discussed earlier, they needed to seek more financial resources. Therefore, the role of the telecentre management committee becomes very important to assist telecentre managers to gain more funding for operational expenses and capital investment in the telecentre program. In addition, other ways of raising money can be achieved through privatisation, for example of commercial services, business one-stop centres among others. Yet there are problems with the injection of fund for telecentres due to the reason that they are controlled by the government. Hence, this restricts their ability to make any profit and become business centres. With sufficient funds, the telecentres would have a high potential to be sustained (APDIP, 2012).

Government funding is usually provided on a short-term basis, and is withdrawn after 3 years (Gaved and Anderson, 2006). The government provides the initial hardware and software and other ICT infrastructure; as illustrated by the telecentres established in 2003 that operated as telecentres with basic ICT facilities and services. The telecentre managers had to think of ways to get additional funding in order to run their telecentre efficiently. Some of the telecentre managers sought the funding from the local champions, but some could not get any funding at all. However, all of the telecentre managers received funding from the services which they charged to the users (at a very minimum charge). As these charges provided limited funding; little effort in program development could be done. This lack of regular ongoing funding hinders the development, success and sustainability of telecentres.

\section{Conclusion}

In conclusion, telecentre sustainability is important in today's development as pillars of sustainability formed a solid argument on telecentre sustainability in Malaysia. These pillars described the criteria and conditions of telecentres which might have the potential to be sustained. Different locations, environment and resources would result in varying chances of sustainability of the telecentres. Having an ideal policy implementation for ICT development would result in improving people's quality of life and economic development especially in rural areas. Therefore, telecentre sustainability is not just about ICT or technology development, but also concerns the rural population (human resources, social development) and financial constraint (economic development).

Technology, physical environments and lack of sufficient number of computers also affect telecentres' sustainability. This suggests that with an injection of sufficient funds, human capital and technology, the telecentres would have more chances to grow up and be sustainable. It is also important to bear in mind the challenges of sustaining telecentres, which are: 1) different stakeholders' interests, and 2) resource constraints (Bailey and Ojelanki, 2009). In summary, sustainable telecentres require resources for providing ongoing support; both for the users and to ensure ongoing operation of the infrastructure (Gaved and Anderson, 2006). This accommodates the different telecentres stakeholders' interests and resource constraints.

Thus, mobilizing resources and funding through partnerships has been an initiative taken by Malaysian government to move forward. Hence, Malaysia has aligned Sustainability Development Goal (SDG 2030) principles with the $11^{\text {th }}$ Malaysia Plan. The adoption of 2030 agenda focus on the National SDG Roadmap sets out the priorities and plan of action for implementation. It is imperative to note that not all telecentres in Malaysia can be sustained. Some have been closed down due to several impediments but some are sustained and developed. However, it is undeniable that with the use of ICT, people will tend to generate more income and improve their quality of life. As a result, the existence of telecentres in the appropriate locations, with adequate funding, infrastructure and resources, will continue to facilitate growth in the economy, and function as agents of rural community development.

\section{Acknowledgement}

The author wishes to extend thanks to Professor Dr. Geoff Cockfield and Dr. Michael Lane for comments and suggestions made on an earlier version of this paper. This work was supported in full by the Universiti Malaysia Terengganu; (financial support) under Talent and Publication Enhancement-Research Grant (TAPE-RG) university grant 2018-2020 (Vote number 55129). 


\section{References}

Abdul Aziz, N., Ong, T. S., Foong, S. Y., Senik, R., \& Attan, H. (2018). Green Initiatives Adoption and Environmental Performance of Public Listed Companies in Malaysia. Sustainability, 10. https://doi.org/10.3390/su10062003

Anwarul, I., \& Keita, S. (2011). Bridging digital divide in Bangladesh: study on community information centers. The Electronic Library, 29(4), 506-522, https://doi.org/10.1108/02640471111156768

APDIP. (2012). Official Portal Asia Pacific Development Information Programme. Bangkok: UNDP. Retrieved from http://www.apdip.net/projects/dig-rev/info/

Attwood, H., \& Braathen, E. (2010). Telecentres and poor communities in South Africa: What have we learnt? In (ICT), P. O. C. E. O. C. P. A. A. T. I. A. C. T. (Ed.), The Chronic Poverty Research Centre (CPRC) Conference. Manchester, UK: National Research Foundation (NRF) and the Norwegian Research Council (NRC).

Bailey, A., \& Ojelanki, N. (2009). Social Ties, Literacy, Location and the Perception of Economic Opportunity: Factors Influencing Telecentre Success in a Development Context. Proceedings of the 42nd Hawaii International Conference on System Sciences, 2009 Hawaii, US. Crown Copyright.

Black, R., \& Atkinson, J. (2007). Addressing the Digital Divide in Rural Australia. Retrieved December 18, 2018, from http://ausweb.scu.edu.au/aw07/papers/refereed/black/paper.html

Breitenbach, M. C. (2013). Telecentres for sustainable rural development: Review and case study of South African Rural telecentre. Development Bank of Southern Africa, 30(2), 262-278. https://doi.org/10.1080/0376835X.2013.797229

Chong, E. T., Poline, B., Sei, P. L., \& Siew, M. W. (2020). The TPOA Telecentre: A Community Sustainable Telecentre Architecture. (IJACSA) International Journal of Advanced Computer Science and Applications, 11(8). https://doi.org/10.14569/IJACSA.2020.0110824

Davies, S., Schwartz, A. W., Pinkett, R. D., \& Servon, I. J. (2003). Community Technology Centres as Catalyst for Community Change.

Essays, UK. (2013). The Green Initiatives In Malaysia Information Technology Essay. Retrieved from https:/www.uniassignment.com/essay-samples/information-technology/thegreen-initiatives-in-malaysiainformation-technology-essay.php?vref=1

Etta, F. E., \& Parvyn-Wamahiu, S. (2003). Information and Communication Technologies for Development in Africa, Volume 2: The Experience with Community Telecentres. Ottawa, ON, CAN, IDRC Books.

Fong, M. W. L. (2009). Digital Divide between Urban and Rural Regions in China. The Electronic Journal on Information Systems in Developing Countries (EJISDC), 36, 1-12. https://doi.org/10.1002/j.16814835.2009.tb00253.x

Furuholt, B., \& Kristiansen, S. (2007). A Rural-Urban Digital Divide? Regional Aspects of Internet Use in Tanzania. The Electronic Journal on Information Systems in Developing Countries (EJISDC), 31, 1-15. https://doi.org/10.1002/j.1681-4835.2007.tb00215.x

Furuholt, B., \& Saebo, O. (2018). The role telecentres play in providing e-government services in rural areas. A longitudinal study of internet access and e-government services in Tanzania. Electronic Journal of Information Systems in Developing Countries. https://doi.org/10.1002/isd2.12006

Gaved, M., \& Anderson, B. (2006). The Impact of local ICT initiatives on social capital and quality of life. Colchester: University of Essex, UK.

Gnaniah, J., Yeo, A. W., Zen, H., Songan, P., \& Ab. Hamid, K. (2006). e-Bario and e-Bedian Project Implementation in Malaysia. https://doi.org/10.4018/978-1-59140-575-7.ch038

Gomez, R. (2012). Libraries, Telecentres, Cybercafés and Public Access to ICT: International Comparisons. IGI Global. https://doi.org/10.4018/978-1-60960-771-5

Gurstein, M. (2000). Community Informatics: enabling communities with communication technologies. Hershey, PA: Idea Group Publishing. https://doi.org/10.4018/978-1-878289-69-8

Harris, R. (2005). Info-mobilization: understanding and making use of the relationship Between ICT and development. Retrieved March 1, 2005, from http://rogharris.org/understandingtherelationship.pdf

Harris, R. (2007). Telecentre 2.0. APDIP e-Note 14. Retrieved August 11, 2007, from http://www.apdip.net/apdipenote/14.pdf 
Harris, R. (2007). Telecentre Sustainability: Financing ICTs for the poor, APDIP e- Note 15/ 2007. Retrieved from http://www.unapcict.org/ecohub/resources/apdip-e-note-15-telecentre-sustainability

Harris, R. et al. (2003). Sustainable telecentres? Two cases from India. In S. Krishna, \& S. Madon (Eds.), The Digital Challenge: Information Technology in the Development Context (pp. 124-135). Burlington: Ashgate Publishing Company.

Hoque, S. M. S., Mahiuddin, K. M., \& Al Muneem, A. (2019). Government E-service delivery in rural Bangladesh: A public-private partnership approach. European Journal of Business and Management, 11(2).

ITU, International Telecommunication Union. (2011a). ITU Contribution to the implementation of the WSIS outcomes. November 2010 to May 2011. May 2011 ed.: International Telecommunication Union World Summit on the Information Society.

ITU, International Telecommunication Union. (2011b). Measuring the Information Society. Geneva, Switzerland: Telecommunication Development Bureau.

Jalaluddin, A. M., Norizan, A. R., Jamaluddin, A. (2010). Tecenter Serumpun Malaysia- Indonesia: Mencari Metod Pembangunan Telecenter Pelbagai Fungsi (MCT). Geografia OnlineTM Malaysian Journal of Society and Space, 6(3), 56-75.

Jensen, M., \& Esterhuysen, A. (2001). The Community Telecentre Cookbook for Africa Recipes for SelfSustainability: How to Establish a Multi-purpose Community Telecentre in Africa. Paris: United Nations Educational Scientific and Cultural Organization.

Kapondera, S., \& Namusanya, D. M. (2017). Uses, benefits and challenges of using rural community telecentres as tools for development: The case of Vikwa community telecentre in Kasungu, Malawi. Journal of Development and Communication Studies, 5(1). https://doi.org/10.4314/jdcs.v5i1.1

Lee, J. C. (2010). Tensions in a Nepali telecenter: An ethnographic look at progress using activity theory (Order No. 3427658). Retrieved from https://search.proquest.com/docview

Lwoga, E. T., \& Chigona, W. (2019). Perception, usage and barriers towards the utilization of the Telecentre among rural women in Tanzania. Journal of Information, Communication and Ethics in Society, 17(1). https://doi.org/10.1108/JICES-01-2018-0004

Mahendhiran, N. (2010). Determinants of the Digital Divide in Rural Communities of a Developing Country: The Case of Malaysia. FAGS.org. https://doi.org/10.21588/dns.2010.39.1.006

Malaysian Communications and Multimedia Commission (MCMC). (2013). Program Jalur Lebar Pusat Internet 1Malaysia Untuk Rakyat Termiskin Di Bandar, Suruhanjaya Komunikasi dan Multimedia Malaysia. Retrieved January 3, 2017, from http://pilm.skmm.gov.my/PJL_FAQ.htm

Marhaini M. N. (2013). Evaluating the Contribution of Community Informatics to Rural Development: The Case of Malaysia's Rural Internet Centres. PhD thesis unpublished.

Marhaini, M. N., \& Abdul Rauf, A. (2014). The Significant Roles of Internet Centre (Information Providers) to rural community in Malaysia. Journal of Administrative Science (JAS), 11(2).

Muhammad Sani, B., Bahaman, A. S., Zahid, E., Muhammad Badsar, Hayrol, A. M. S., \& Abdul Ra’uf, A. (2011). Information and Communication Technology Development in Malaysia: Influence of Competency of Leaders, Location, Infrastructures and Quality of Services on Telecentre Success in Rural Communities of Malaysia. Australian Journal of Basic and Applied Sciences, 5(9), 1718-1728.

Murray, B., Murray, C., \& Brooks, S. (2001). Training Telecentre Managers, Staff and Users. In Colin, L., \& David, W. (Eds.), Perspectives On Distance Education Telecentres: Case studies and key issues. Vancouver: The Commonwealth of Learning.

Nemer, D. (2015). Rethinking digital inequalities: The experience of the marginalized in community technology centers (Order No. 3722272). Retrieved from https://search.proquest.com

Niranjan, M. (2009). E3-Framework for Telecenter Network Sustainability Development. Retrieved from https://www.researchgate.net/scientific.../2029131826_Niranjan_Meegammana

Parkinson, S. (2003). The impact of the internet on local social equity: A study of a telecentre in aguablanca, Colombia (Order No. MQ80186). Retrieved from https://search.proquest.com/docview/

Pigg, K. E. (2003). Applications of Community Informatics for Building Community and Enhancing Civic Society. Information, Communication and Society, 4, 507-527. https://doi.org/10.1080/13691180110096996 
Prado, P., \& Janbek, D. M. (2013). Telecenter Web Portals in Latin American and Arab Nations: A Comparative Analysis. Journal of community informatics, 9. https://doi.org/10.15353/joci.v9i1.3186

Proenza, F. J., Bastidas-Buch, R., \& Montero, G. (2001). Telecentres for Socioeconomic and Rural Development in Latin America and the Caribbean: Investment Opportunities and Design Recommendations, with special reference to Central America. Washington D.C.: Inter-American Development Bank.

Raul, R. (2000). Towards a Training Framework for Telecenter Managers. Ithaca, NY.: Cornell University.

Raul, R., \& Colle, R. D. (2002). Themes and Issues in Telecentre Sustainability. Development Informatics. Manchester, UK: Institute for Development Policy and Management, University of Manchester, UK.

Short, G. (2001). The Western Australia Telecentre Network (WATN). In Colin, L., \& David, W. (Eds.), Perspectives On Distance Education Telecentres: Case studies and key issues. Vancouver: The Commonwealth of Learning.

Simms, S. S. (2004). Internet use, social capital and development (Order No. 3133231). Retrieved from https://search.proquest.com/docview/305205874? accountid=45905

Skaletsky, M. (2013). Essays on the digital divide - explorations through global, national and individual lenses (Order No. 3587811). Retrieved from https://search.proquest.com/docview/14273406

Smoot, D. M. (2007). Bridging the digital divide: A qualitative study of two educators narrowing the gap (Order No. 3280227). Retrieved from https://search.proquest.com/docview/

Telecentre, O. (2011). Annual Report: A review of the year 2011. Quezon City, Phillipines: Telecentre org Foundation.

Tizala-Jatoe, E. (2011). Telecenters and community economic development in peri-urban areas of ghana (Order No. MR80017). Retrieved from https://search.proquest.com/docview/

UN. (2006). Encyclopedia Britannica.

UN-APCICT. (2010). United Nations-Asia and Pacific Training Centre for ICT for Development. Korea: UNESCAP. Retrieved December 3, 2018, from http://www.unapcict.org/ecohub/resources/browseresources/telecentres

UNDP. (2001). Human Development Report 2001. Making Technologies Work for Human Development. Washington, D.C.

UNIMAS. (2019). Telecentre Programme For Orang Asli (TPOA). Official portal of Universiti Malaysia Sarawak. Retrieved from http://www.isiti.unimas.my/about-isiti/64-research/research-projects\#

Van Dyk, L. (2018). The Manifestation of Sustainability in Social Enterprises. The International Journal of Sustainability Policy and Practice, 14(1). https://doi.org/10.18848/2325-1166/CGP/v14i01/1-16

World Bank. (2019). Information and Communications for Development 2018. Data-driven Development. World Bank Group, Washington, USA.

Zaitun, A. B., \& Crump, B. (2005). Overcoming the digital divide-a proposal on how institutions of higher education can play a role. Malaysian Online Journal of Instructional Technology, 2(1), 1-11. 


\section{Appendix: Percentage of individuals using the internet (2005-2019)}

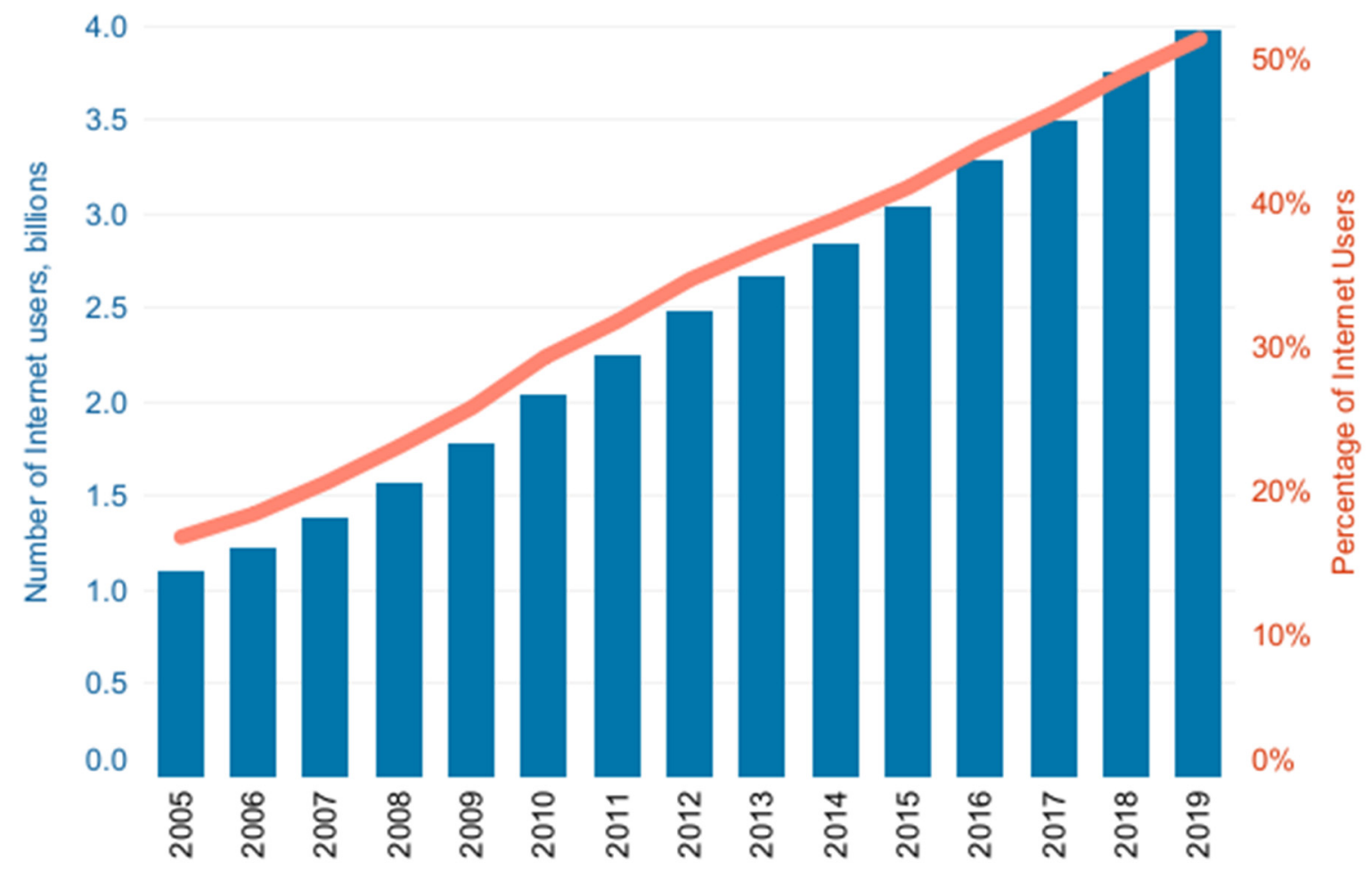

Source: ITU

\section{Copyrights}

Copyright for this article is retained by the author(s), with first publication rights granted to the journal.

This is an open-access article distributed under the terms and conditions of the Creative Commons Attribution license (http://creativecommons.org/licenses/by/4.0/). 